Tropical Journal of Pharmaceutical Research June 2016; 15 (6): 1167-1174

ISSN: $1596-5996$ (print); 1596-9827 (electronic)

(C) Pharmacotherapy Group, Faculty of Pharmacy, University of Benin, Benin City, 300001 Nigeria.

All rights reserved.

Available online at http://www.tjpr.org

Original Research Article

http://dx.doi.org/10.4314/tjpr.v15i6.8

\title{
Apoptotic properties of Citrus sudachi Hort, ex Shirai (Rutaceae) extract on human A549 and HepG2 cancer cells
}

\author{
Ji Hye Kim ${ }^{1}$ and Min Young Kim ${ }^{1,2 *}$ \\ ${ }^{1}$ Toxicology Laboratory, Major in Biomaterials, College of Applied Life Science, SARI, ${ }^{2}$ Research Institute for Subtropical \\ Agriculture and Biotechnology, Jeju National University, Jeju, Republic of Korea
}

*For correspondence: Email: jeffmkim@jejunu.ac.kr; Tel: +82-64-754-3349; Fax: +82-64-756-3351

Received: 19 February 2016

Revised accepted: 22 May 2016

\begin{abstract}
Purpose: To investigate whether Citrus sudachi harvested at two stages of maturity can induce toxicity in a cell-specific manner and to determine the possible mechanisms of Citrus sudachi-induced cytotoxic responses in two types of cancer cells (human lung adenocarcinoma A549 and hepatocellular carcinoma HepG2 cells) and two normal cell lines (lung 16HBE140- and liver CHANG cells).

Methods: 3-(4,5-Dimethylthiazol-2-yl)-2,5-diphenyltetrazolium bromide (MTT) and annexin V/propidium iodidle assay were used to test the antiproliferative activity and apoptosis of methanol extract of Citrus sudachi, respectively. Griess reaction and reverse transcriptase-polymerase chain reaction (RT-PCR) were carried out to evaluate nitric oxide $\left(N^{\circ}\right)$ production and the mRNA levels of inhibitors of apoptosis (IAP).

Results: Citrus sudachi exerted cytotoxicity in a time-dependent manner in cancer cells which increased with increase in maturity but did not affect normal cells. Citrus sudachi was found to induce accumulation of cells in the sub-G1 cell cycle phase, fragmentation of DNA and cell death with characteristics of apoptosis, in both types of cancer cells. Moreover, Citrus sudachi upregulated cellular NO produced by activation of nitric oxide synthase (NOS), while it suppressed the levels of IAP mRNA in both types of cancer cells.

Conclusion: The results obtained suggest that Citrus sudachi induces apoptosis in A549 and HepG2 cells, which may be mediated by NO. There is need for further studies on the role of Citrus sudachi in cancer treatment.
\end{abstract}

Keywords: Apoptosis, Citrus sudachi, Human lung and liver cancer cells, Inhibitors of apoptosis, Nitric oxide

Tropical Journal of Pharmaceutical Research is indexed by Science Citation Index (SciSearch), Scopus, International Pharmaceutical Abstract, Chemical Abstracts, Embase, Index Copernicus, EBSCO, African Index Medicus, JournalSeek, Journal Citation Reports/Science Edition, Directory of Open Access Journals (DOAJ), African Journal Online, Bioline International, Open-J-Gate and Pharmacy Abstracts

\section{INTRODUCTION}

Lung cancer is the leading cause of cancer death worldwide; it is responsible for 1.59 million deaths annually [1]. Liver cancer is the third leading cause of cancer death, causing 745,000 deaths per year as of 2012 [1]. Continuous efforts are being made to find novel, naturally occurring bioactive compounds that prevent lung and liver cancer because of the adverse effects that are often associated with artificial chemotherapeutic agents [1].

Citrus sudachi Hort. ex Shirai (Rutaceae), or, simply, sudachi, is primarily used as a seasoning in savory foods and as a flavoring in alcoholic beverages in Japanese cuisine but also used in other Asian food. Citrus sudachi is harvested before the fruit is fully ripe, while still green, because the flavor and odor are strongest at that 
stage. As the green color disappears, the acceptance of the fruit by consumers is gradually reduced. When fully ripe, the fruit turns yellowish, but it is generally used before that stage.

Citrus sudachi contains high levels of polyphenols and flavonoids [2-4]. Flavonoids extracted from the peel of Citrus sudachi have been shown to exhibit several biological activities that are beneficial to health including antioxidant, anti-inflammatory, antimicrobial, and antidiabetic properties [5-9]. These beneficial properties suggest new uses for Citrus sudachi as a nutraceutical, and studies of the immature and mature fruits of Citrus sudachi are currently of considerable interest in the pharmaceutical and food industries. However, the anticancer effects of Citrus sudachi have never been investigated.

The purpose of this study was to investigate the cytotoxic effects of Citrus sudachi harvested at two stages of maturity (immature and mature) on two tumor cell lines, human lung adenocarcinoma and hepatocellular carcinoma cells. This study demonstrate that nitric oxide (NO•) and Inhibitors of apoptosis (IAPs) is necessary for the anti-tumoral capacity of Citrus sudachi, thus providing a strong basis for understanding the molecular mechanisms of apoptosis in A549 and HepG2 cells.

\section{EXPERIMENTAL}

\section{Plant material and extraction}

Immature and mature Citrus sudachi fruits were harvested in September and November of 2014, respectively, on Jeju Island, Korea. The Citrus sudachi was mostly grown in Korea. No specific permissions are required for getting in Korea. Citrus sudachi was identified by Professor Jung Hyun Kim from Cheju Tourism College. Immature and mature Citrus sudachi fruits were then thoroughly rinse with tap and distilled water and were air-dried at room temperature. The air-dried fruits were grounded into powder using a blender.

Dried powder $(5 \mathrm{~g})$ of Citrus sudachi was extracted with $100 \mathrm{ml}$ of $100 \%$ methanol at 25 ${ }^{\circ} \mathrm{C}$ for $72 \mathrm{~h}$ with constant shaking. The extract was then purified using a Sep-Pak C18 cartridge and a $0.45 \mu \mathrm{m}$ membrane filter (Waters, Milford, MA, US), concentrated using a rotary evaporator (Buchi Rotavapor R-200, New Castle, DE, US), freeze dried and finally stored at $-20{ }^{\circ} \mathrm{C}$ until further use. Dried extracts were reconstituted in dimethyl sulfoxide (DMSO, Amresco, Solon, Ohio, USA) for cell treatment.

\section{Cell culture}

Human lung cancer (A549), normal lung (16HBE140-) cells, human liver cancer (HepG2) and normal liver (CHANG) cells were kindly provided by Dr. M.H. Cho (Seoul National University, Korea). A549 and 16HBE140 cells were grown in HAM's F-12 and DMEM/F-12 media, respectively. HepG2 and CHANG cells were maintained in MEM and DMEM media, respectively. The cells were cultured in the appropriate media containing $10 \%$ fetal bovine serum (FBS), $1 \%$ penicillin/streptomycin, and 1 $\%$ L-glutamine at $37^{\circ} \mathrm{C}$ and $5 \% \mathrm{CO}_{2}$.

\section{Cell viability assay}

Cell viability was estimated using trypan blue as described previously [10]. Cells were seeded in $100 \mathrm{~mm}$ cell culture dishes at $2 \times 10^{7}$ cells $/ 10 \mathrm{ml}$. The cultured cells were treated with fresh medium containing various concentrations (0-200 $\mu \mathrm{g} / \mathrm{ml}$ ) of the Citrus sudachi extracts dissolved in dimethyl sulfoxide (Amresco, Solon, Ohio, USA). DMSO alone was added to another set of cells as a solvent control (DMSO $<0.1 \%$ ).

The cells were then incubated for 24,48 , or $72 \mathrm{~h}$, detached with trypsin, and then an equal volume of $0.4 \%$ trypan blue solution (Lonza, Walkersville, MD, US) was added. After $1 \mathrm{~min}$ incubation, viable cells were counted with a hematocytometer. All experiments were done in triplicate.

\section{Cell cycle analysis}

Flow cytometric analysis was performed as previously described [11]. Cells $\left(2 \times 10^{7}\right.$ cells $/ 10$ $\mathrm{ml}$ ) were treated with Citrus sudachi extracts for $72 \mathrm{~h}$. They were then harvested and washed twice with $1 \mathrm{ml}$ PBS, then centrifuged at 1000 $\mathrm{rpm}$ for $10 \mathrm{~min}$ at $4{ }^{\circ} \mathrm{C}$. Pellets were fixed with 70 $\%$ ethanol and kept on ice for $30 \mathrm{~min}$. The cells were stained with $500 \mu \mathrm{g} / \mathrm{ml}$ of propidium iodide (Sigma, Louis, MO, USA) on ice, digested with $10 \mu \mathrm{g} / \mathrm{ml}$ of ribonuclease A (Amresco) at $37^{\circ} \mathrm{C}$ for $30 \mathrm{~min}$, and analyzed with a BD FACS caliburTM flow cytometer (BD biosciences, San Jose, CA, US). The percentage of cells with DNA content less than $2 \mathrm{~N}$ (sub-G1 phase cells) was analyzed with CELL QUEST software.

\section{DNA fragmentation}

A GeneluteTM mammalian genomic DNA miniprep kit (Sigma) was used to perform a DNA laddering assay [10]. To detect the DNA ladder, the extracted DNA samples were run on a $1.8 \%$ agarose gel in TBE buffer. After electrophoresis, 
the gels were stained with ethidium bromide (EtBr, Sigma) and visualized with a UV light transilluminator.

\section{Determination of nitrite production}

The amount of $\mathrm{NO}^{\circ}$ in the culture medium was measured by the Griess reaction as previously described [11]. Furthermore, $100 \mu$ of cell culture media was mixed with an equal volume of Griess reagent and incubated at room temperature for $10 \mathrm{~min}$.

Absorbance at $540 \mathrm{~nm}$ was measured using a Packard EL430 microplate reader (Bio-Tek Instruments, Winooski, VT, US), with fresh culture media serving as the blank. Results are expressed in $\mu$ moles per $10^{4}$ viable cells.

\section{Reverse transcription-polymerase chain reaction (RT-PCR) analysis}

Total cellular RNA was isolated from each cell line using TRI reagent (Sigma) and semiquantitative RT-PCR analysis was carried out using a TOP scriptTM one-step RT-PCR kit (Enzynomics, Daejeon, Korea) [11]. Primer sequences were as follows: iNOS, sense 5'CCAGTGACACAGGATGACCTTCAG-3' and antisense 5'-TGCCATTGTTGGTGGAGTAACG37'; survivin, sense 5'-GCATGGGTGCCCCGA CGTTG-3 $\neg$ ' and antisense 5'-GCTCCGGCCAG AGGCCTCAA-3 '; XIAP, sense 5'ACACCATATACCCGAGGA AC-3 $\neg$ and antisense 5'-CTTGCATACTGTCTTTCTGAGC3ᄀ': clAP-1, sense 5'-AAGTTCCTACCCCT GTCCAATG-3 $\neg$ ' and antisense 5'CAAGTAGATGAGGGTAACTGGC-3;, clAP-2, sense 5'-CCTGTGGTTAAATCTGCCTTG-3'יר' and antisense 5'-CAATTCGGCACCATAACTCT G-3'; and $\beta$-actin, sense 5'-GGTCATCTTC TCGCGGTTGGCCTTGGGGT-3' and antisense 5'-CCCCAGGCACCAGGGCGTGAT-3'. $2 \mu \mathrm{g}$ of total RNA was used in each reaction and was amplified in the exponential phase of PCR. Reactions were normalized to actin levels. Amplified DNA was electrophoresed on $1.5 \%$ agarose gels and visualized by $\mathrm{EtBr}$ staining.

\section{Statistical analysis}

Data are presented as mean \pm SD. Statistical analysis was done using a Student's t-test (SPSS for Windows, 12.0, SPSS Inc. Chicago, IL, USA). Differences were considered significant at $p<0.05$.

\section{RESULTS}

\section{Loss of cell viability}

In this study, we examined the cytotoxicity of Citrus sudachi on A549 and HepG2 cells. Cells treated with $0,50,100$, and $200 \mu \mathrm{g} / \mathrm{ml}$ of Citrus sudachi harvested at two stages of maturity (immature and mature) for $24 \mathrm{~h}$ responded similarly, with respect to viability, in that treatment with extracts from immature and mature fruits reduced the percentage of viable cells dose-dependently (data not shown). We then determined the time course of responses to $200 \mu \mathrm{g} / \mathrm{ml}$ of immature and mature Citrus sudachi in cancerous and normal cells treated for 24, 48, or $72 \mathrm{~h}$ (Figure 1). The human lung adenocarcinoma cell line (A549) was more susceptible to Citrus sudachi to cell death than hepatocellular carcinoma cell line (HepG2). Exposure to $200 \mu \mathrm{g} / \mathrm{ml}$ of immature Citrus sudachi for $72 \mathrm{~h}$ reduced the viability of $\mathrm{A} 549$ and HepG2 cells to 35 and $46 \%$, respectively, whereas comparable values were found after treatment with mature Citrus sudachi (32 and 55 $\%$, respectively) (Figure 1 ). The extracts were not cytotoxic to either of the normal cell lines, indicating the potential specificity of the Citrus sudachi extracts against lung and liver cancer cells (Figure 1).

\section{Apoptosis identified by flow cytometric analysis}

The population of cells in the sub-G1 phase in cells treated with $200 \mu \mathrm{g} / \mathrm{ml}$ of immature Citrus sudachi increased from $3.6 \%$ (control level) to $12.2 \%$, whereas treatment with extract from mature Citrus sudachi increased the proportion of A549 cells in cell cycle arrest to $19.9 \%$ (Figure 2). Furthermore, treatment with immature and mature Citrus sudachi extracts resulted in increase in the sub-G1 population to 10.1 and 9 $\%$ in HepG2 cells, respectively (Figure 2).

\section{Internucleosomal DNA fragmentation}

Our results revealed fragmentation of DNA following treatment of A549 and HepG2 cells with Citrus sudachi extracts, indicating the presence of apoptosis, whereas DNA fragmentation was not seen in non-cancerous cells (Figure 2C). Mature Citrus sudachi resulted in a significant increase in the intensity of DNA laddering when compared with immature Citrus sudachi (Figure 2C). These findings indicate that Citrus sudachi can induce apoptosis-mediated cell death in 
A549 and HepG2 cells, but does not cause apoptotic cell death in normal cells.

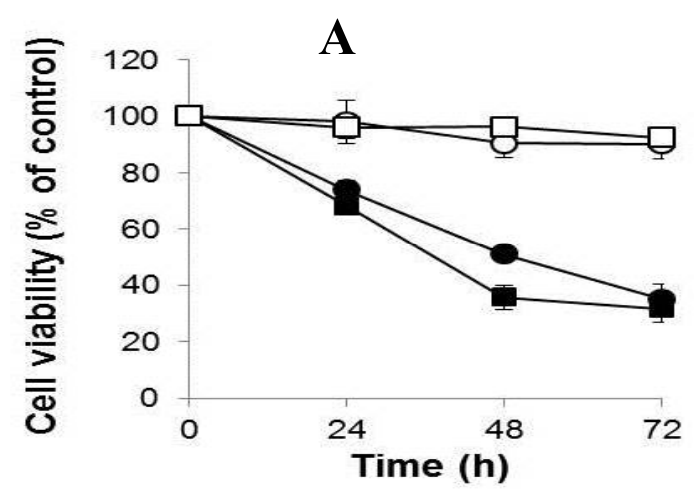

B

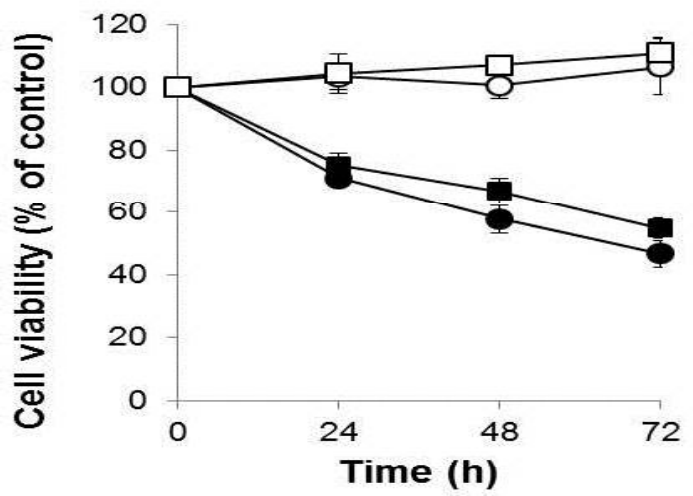

Figure 1: Time-dependent growth inhibition of human lung cancer A549 (immature, $\bullet$; mature, $\mathbf{a}$ ) and normal 16HBE140- cells (immature, o; mature, г) (A), and human liver cancer HepG2 (immature, $\bullet$; mature, a) and normal CHANG (immature, o; mature, $\sqsubset$ ) cells (B) by immature and mature Citrus sudachi extracts (200 $\mu \mathrm{g} / \mathrm{mL}$ ) after 24,48 and $72 \mathrm{~h}$. Values are expressed as mean \pm SD of three independent experiments

\section{Expression of NOS isoenzyme proteins and total $\mathrm{NO}^{\circ}$ production}

In order to determine the role of $\mathrm{NO}^{\circ}$ in apoptosis induced by Citrus sudachi, expression of iNOS and nitrite $\left(\mathrm{NO}_{2}{ }^{-}\right)$production is determined in A549 and HepG2 cells (Figure 3). Immature and mature Citrus sudachi markedly up-regulated iNOS in both types of cancer cells; the increase was more pronounced in A549 cells (Figure 3A). Rates of NO production were calculated from the concentration of $\mathrm{NO}_{2}^{-}$in culture media following treatment for $72 \mathrm{~h}$. Cells treated with either immature or mature Citrus sudachi extract alone showed 2- to 7-fold increases in $\mathrm{NO}^{\circ}$ production, as compared with vehicle-treated controls (Figure 3B).

\section{Changes in mRNA of IAP family caused by Citrus sudachi}

In this study, we investigated the mechanisms underlying cell death induced by Citrus sudachi, with a focus on the role of IAP family members (survivin, XIAP, clAP-1, and clAP-2). As shown Figure 4, treatment with Citrus sudachi extracts for $72 \mathrm{~h}$ led to a reduction in survivin and cellular IAP-2 (clAP-2) gene expression in both A549 and HepG2 cells. Meanwhile, the mRNA levels of clAP-1 were enhanced by Citrus sudachi, but no differences were observed in mRNA levels of the X-chromosome-linked IAP (XIAP) (Figure 4).

\section{DISCUSSION}

Citrus sudachi is a plant with numerous health benefits including nutritional and medicinal advantages $[5,8,9]$. Medicinal plants are a common alternative to pharmacological cancer treatment in many countries. Cytotoxic screening of a number of plants has been done in order to investigate their anticancer activities and usefulness in drug development [12]. The aim of this work was to explore the biochemical and molecular events associated with programmed cell death in melanoma after treatment with Citrus sudachi harvested at two stages of maturity (immature and mature). Anticancer activities of Citrus fruit varieties have been found in other studies [13-16]. For instance, Citrus limon and Citrus paradise demonstrate cytotoxic activity in vitro against human prostate, lung, and breast cancer cell lines [13]. Qing Pi (Citri reticulatae viride pericarpium, immature tangerine peel) also strongly induced apoptosis in SNU-C4 human colon cancer cells [14]. The flavonoids extracted from Citrus fruits have been shown to inhibit the proliferation of A549 human lung adenocarcinoma cells $[15,16]$. Our results have clearly demonstrated that immature and mature Citrus sudachi inhibit cell growth and promote apoptosis in cell lines A549 and HepG2 (Figures 1 and 2). When developing anticancer agents from natural products, it is important not only to assess the selectivity (or specificity) in several types of cancer cells but also to assess if natural products exhibit any cytotoxicity in noncancer cell lines [12]. Thus, the cytotoxic effects of immature and mature Citrus sudachi on the 16HBE140- (normal human bronchial epithelial cells) and CHANG (normal human liver cells) lines was tested. Given the fact that no cytotoxic effects were observed against normal cells, our data clearly indicates that Citrus sudachi exert a selective antiproliferative activity against lung and liver cancer cells (Figure 1). Citrus sudachi 
A

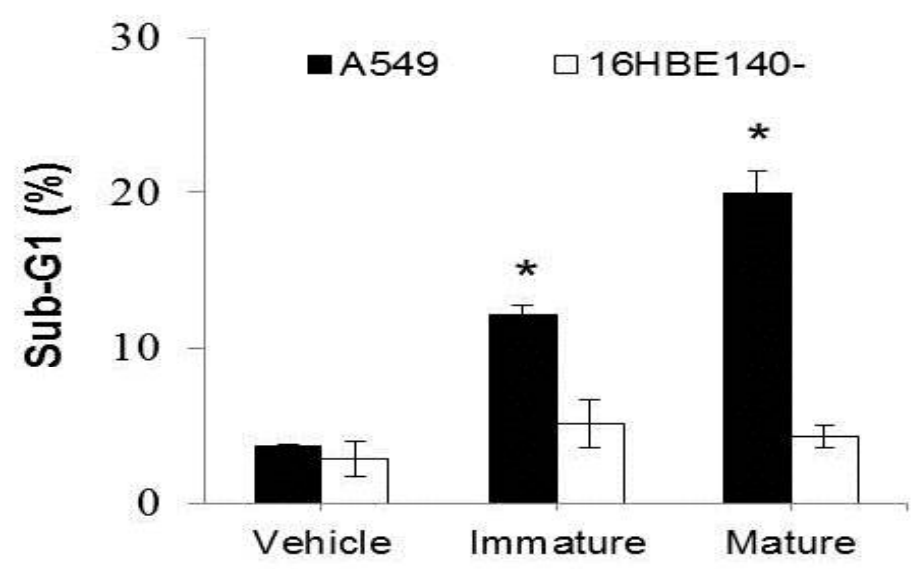

B
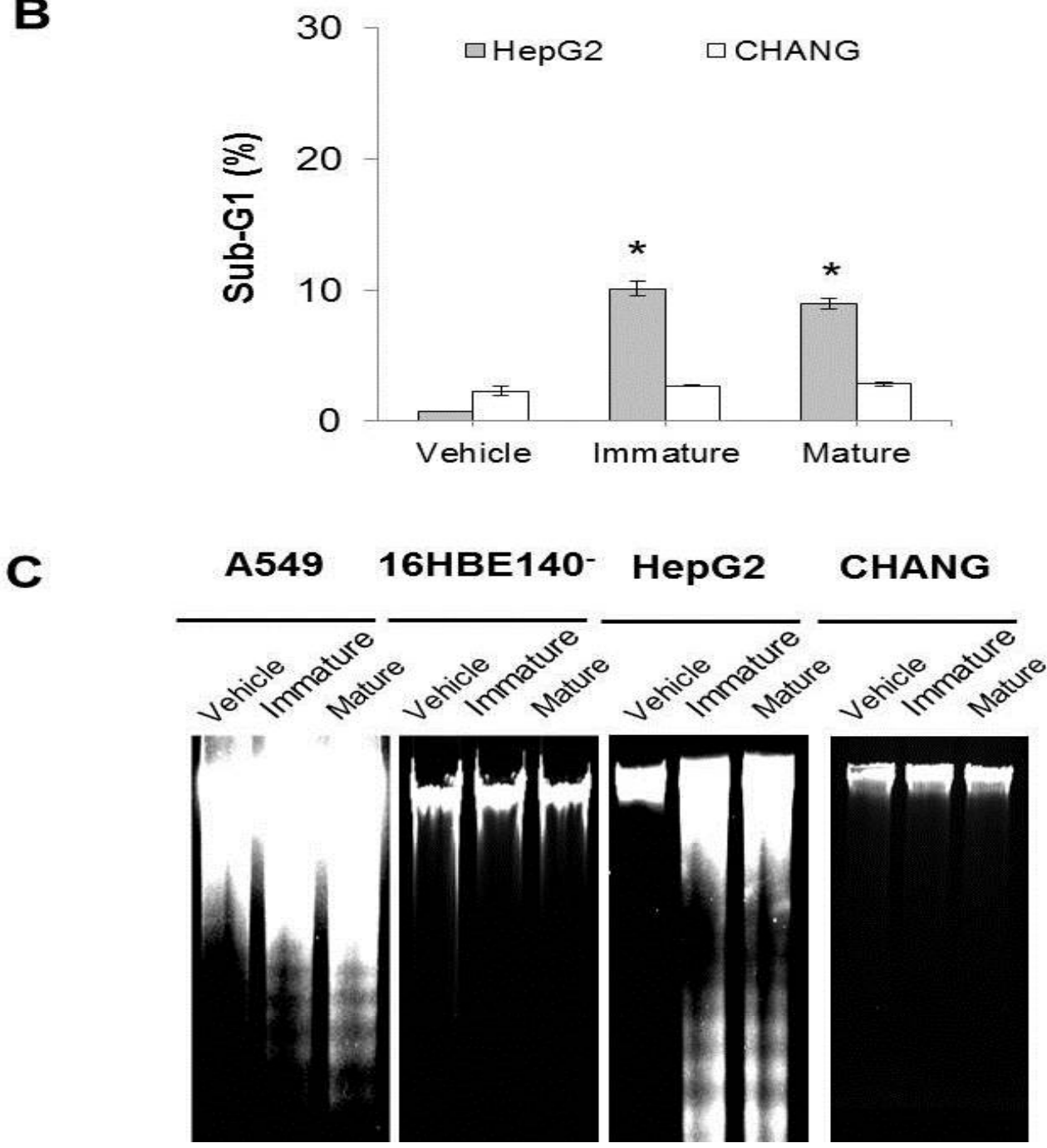

Figure 2: Induction of apoptosis by immature and mature Citrus sudachi extracts $(200 \mu \mathrm{g} / \mathrm{mL})$ after $72 \mathrm{~h}$. Apoptotic cell population (sub-G1) by PI method in human lung cancer A549 and normal 16HBE140- cells (A), and human liver cancer HepG2 and normal CHANG cells (B). Confirmation of apoptosis mediated cell death in A549 and HepG2 cells through observation of DNA laddering using DNA fragmentation assay (C). Results (A and B) are shown as the mean $\pm \mathrm{SD}(\mathrm{n}=3)$. ${ }^{*}, p<0.05$ compared with vehicle 
A

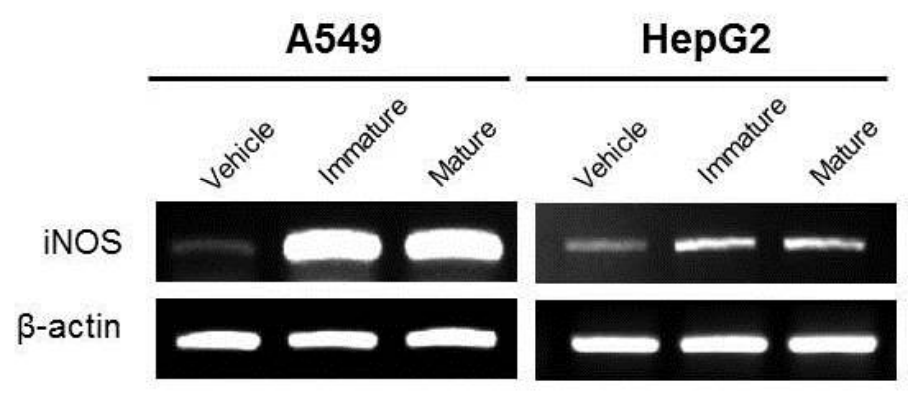

B

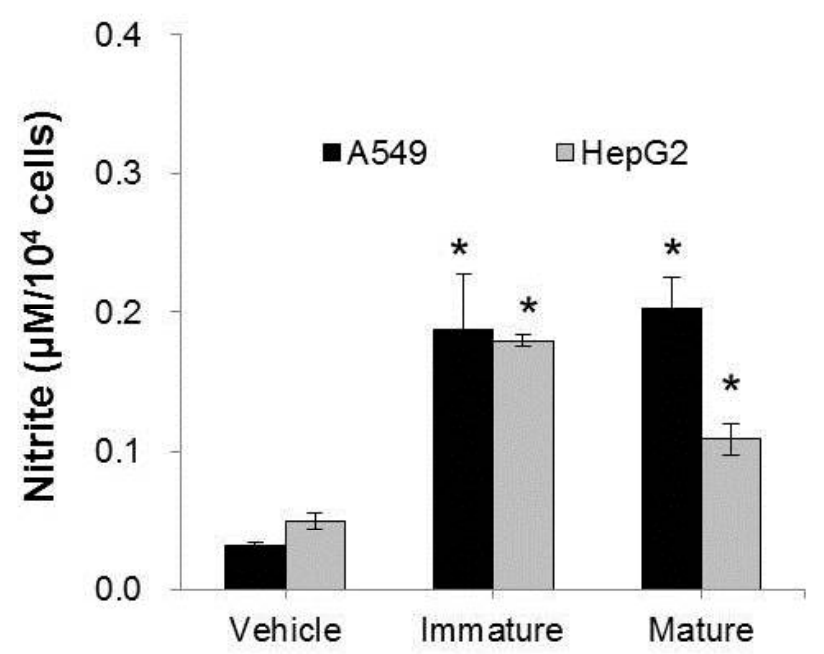

Figure 3: Effect of immature and mature Citrus sudachi extracts $(200 \mu \mathrm{g} / \mathrm{mL}, 72 \mathrm{~h})$ on the expression of NOS isoforms (A) and NO production (B) in A549 and HepG2 cells. Results are shown as the mean \pm SD $(n=3)$. ${ }^{*} p<$ 0.05 compared with vehicle

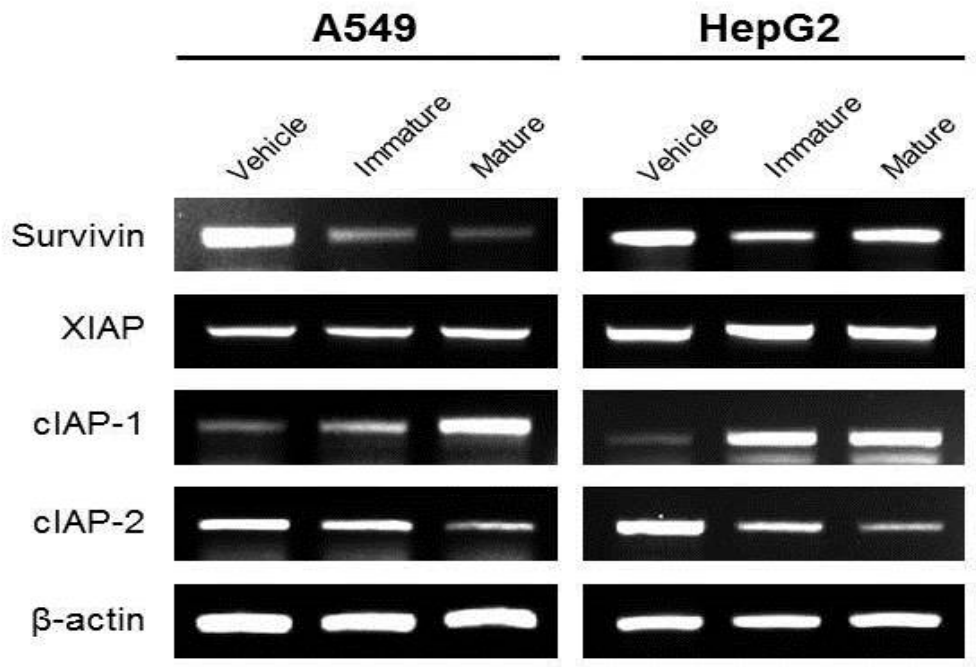

Figure 4: Expression of survivin, XIAP, cIAP-1 and clAP-2 mRNA in A549 and HepG2 cells after treatment with Citrus sudachi extracts $(200 \mu \mathrm{g} / \mathrm{mL})$ for $72 \mathrm{~h}$. Semi-quantitative RT-PCR was performed using primer specific to survivin, XIAP, clAP-1 and clAP-2 or $\beta$-actin control on $1 \mu \mathrm{g}$ total RNA prepared from treated cells 
was tested to evaluate whether this cytotoxic effect is associated with apoptosis. Induction of apoptosis in cancer cells has been used as an indicator of the ability of naturally-derived active components to treat cancer [17]. Fragmentation of DNA into $180-200 \mathrm{bp}$ fractions is considered one of the hallmarks of apoptosis [18]. As shown in Figure 2, DNA fragmentation as well as flow cytometric analysis showed that apoptosis was a major contributor to cell death induced in A549 and HepG2.

Data presented here of increased NO. production with Citrus sudachi treatment and the activation of iNOS level, suggest that $\mathrm{NO}$ regulation accounts for the mechanism of Citrus sudachi's action in these cell lines. $\mathrm{NO}^{\circ}$ released by the inducible NOS (iNOS) is generated for long periods, by cells of the immune system among others, and has been shown to be a principle factor in inflammatory processes and cancer formation [19]. The role of NO• in cancer is multi-dimensional and depends on timing, location and concentration. High levels of $\mathrm{NO}$. are cytotoxic to cancer cells [19]. The contrast, at low levels, constitutive production of endogenous $\mathrm{NO}^{\circ}$ can promote tumor growth by inducing antiapoptotic effects in many tumor types including melanoma [19-21]. Conflicting evidence exists regarding the ability of Citrus fruit varieties to modulate $\mathrm{NO}^{\circ}$ production. While some investigators found that Citrus enhances iNOS expression and $\mathrm{NO}^{\circ}$ production, others observed suppression. For example, Citrus polyphenol limonene promoted NO- production in several studies, leading to an inhibition in proliferation of human melanoma A375 cells [22], leukemia HL60 cells [23], and epidermoid carcinoma A431 cells [24]. On the other hand, Sudachitin, a polymethoxyflavone from Citrus sudachi, inhibited LPS-mediated NO- production and iNOS protein expression in RAW264.7 macrophages [9], and Citrus nobiletin reduced $\mathrm{NO}$ - levels and decreased iNOS expression in hepatocytes [25]. Our data indicate a direct relationship between increased $\mathrm{NO}$ - production and loss of cell viability (Figs. 1 and 3 ) following treatment with both immature and mature Citrus sudachi extracts. To the best of our knowledge, there are no other reports on the effect of $\mathrm{NO}$. stimulated by Citrus sudachi extracts on the proliferation of cancer cells.

The inhibitor of apoptosis (IAP) family of proteins are important regulators of apoptotic signaling cascades as they block the activity of caspases [26]. Therefore, IAPs are potential targets of Citrus sudachi. In the present study, immature and mature Citrus sudachi exposure suppressed survivin as well as clAP-2 mRNA expression in both A549 and HepG2 cells. Survivin is a structurally and functionally unique IAP in that it contains a single BIR but no RING domain, and plays dual roles in mitosis and apoptosis [27]. clAP-2 regulates not only caspases and apoptosis, but also inflammatory signaling and immunity, mitogenic kinase signaling, and cellular proliferation, as well as cell invasion and metastasis [28]. Notably, Citrus fruits reduce the anti-apoptotic signals of IAP proteins, thus facilitating the process of apoptosis in human melanoma A375 [21] and leukemia U937 [29] cells. Our results show for the first time that Citrus sudachi induces apoptosis in lung and liver cancer cells and revealed the role of the IAPs survivin and clAP-2 in the process.

\section{CONCLUSION}

Citrus sudachi extracts induce apoptosis in A549 and HepG2 cells via $\mathrm{NO}^{\circ}$ production and down regulation of IAPs, and that the effects depend on the growth stage of Citrus sudachi. This is the first report to reveal the possible mechanism of the antiproliferative effect of Citrus sudachi for the prevention of lung and liver cancer in cell culture model. However, further studies are needed to validate our finding in detailed in vivo studies.

\section{ACKNOWLEDGEMENT}

This work was supported by the research grant from Chuongbong Academic Research Fund of Jeju National University in 2014.

\section{DECLARATIONS}

\section{Conflict of Interest}

No conflict of interest associated with this work.

\section{Contribution of Authors}

The authors declare that this work was done by the authors named in this article and all liabilities pertaining to claims relating to the content of this article will be borne by them.

\section{REFERENCES}

1. Ferlay J, Soerjomataram I, Dikshit R, Eser S, Mathers C, Rebelo M, Parkin DM, Forman D, Bray F. Cancer incidence and mortality worldwide: Sources, methods and major patterns in globocan 2012. Int $J$ Cancer, 2015; 136: E359-386

2. Nakagawa $H$, Duan H, Takaishi Y. Limonoids from citrus sudachi. Chem Pharm Bull (Tokyo), 2001; 49: 649-651 
3. Akakabe Y, Sakamoto M, Ikeda Y, Tanaka M. Identification and characterization of volatile components of the japanese sour citrus fruit citrus nagato-yuzukichi tanaka. Biosci Biotechnol Biochem, 2008; 72: 1965-1968

4. Nakagawa H, Takaishi Y, Tanaka N, Tsuchiya K, Shibata $H$, Higuti T. Chemical constituents from the peels of citrus sudachi. J Nat Prod, 2006; 69: 1177-1179

5. Tomotake $H$, Koga $T$, Yamato $M$, Kassu A, Ota F. Antibacterial activity of citrus fruit juices against vibrio species. J Nutr Sci Vitaminol (Tokyo), 2006; 52: 157-160

6. Higashimoto $M$, Yamato $H$, Kinouchi $T$, Ohnishi $Y$. Inhibitory effects of citrus fruits on the mutagenicity of 1methyl-1,2, 3,4-tetrahydro-beta-carboline-3-carboxylic acid treated with nitrite in the presence of ethanol. Mutat Res, 1998; 415: 219-226

7. Nii Y, Fukuta K, Sakai K, Yamamoto S. Japanese citrus fruit (sudachi) juice is associated with increased bioavailability of calcium from whole small fish and suppressed bone resorption in rats. J Nutr Sci Vitaminol (Tokyo), 2004; 50: 177-183

8. Tsutsumi R, Yoshida $T$, Nii $Y$, Okahisa N, Iwata S, Tsukayama M, Hashimoto R, Taniguchi Y, Sakaue H, Hosaka $T$, et al. Sudachitin, a polymethoxylated flavone, improves glucose and lipid metabolism by increasing mitochondrial biogenesis in skeletal muscle. Nutr Metab (Lond), 2014; 11: 32

9. Yuasa K, Tada K, Harita G, Fujimoto T, Tsukayama M, Tsuji A. Sudachitin, a polymethoxyflavone from citrus sudachi, suppresses lipopolysaccharide-induced inflammatory responses in mouse macrophage-like raw264 cells. Biosci Biotechnol Biochem, 2012; 76: 598600

10. Kim MY. Nitric oxide triggers apoptosis in a375 human melanoma cells treated with capsaicin and resveratrol. Mol Med Rep, 2012; 5: 585-591

11. Byun JH, Kim MY. Inhibition of endogenous nitric oxide promotes p53-dependent apoptosis induced by cisplatin in human colon cancer cells. Life Sci J, 2012; 19: 399406

12. Tundis R, Loizzo MR, Menichini F. An overview on chemical aspects and potential health benefits of limonoids and their derivatives. Crit Rev Food Sci Nutr, 2014; 54: 225-250

13. Zu Y, Yu H, Liang L, Fu Y, Efferth T, Liu X, Wu N. Activities of ten essential oils towards propionibacterium acnes and pc-3, a-549 and mcf-7 cancer cells. Molecules, 2010; 15: 3200-3210

14. Kang SA, Park HJ, Kim MJ, Lee SY, Han SW, Leem KH. Citri reticulatae viride pericarpium extract induced apoptosis in snu-c4, human colon cancer cells. J Ethnopharmacol, 2005; 97: 231-235

15. Luo G, Guan X, Zhou L. Apoptotic effect of citrus fruit extract nobiletin on lung cancer cell line a549 in vitro and in vivo. Cancer Biol Ther, 2008; 7: 966-973

16. Xiao $H$, Yang CS, Li S, Jin H, Ho CT, Patel $T$. Monodemethylated polymethoxyflavones from sweet orange (citrus sinensis) peel inhibit growth of human lung cancer cells by apoptosis. Mol Nutr Food Res, 2009; 53: 398-406

17. Shu L, Cheung KL, Khor TO, Chen C, Kong AN. Phytochemicals: Cancer chemoprevention and suppression of tumor onset and metastasis. Cancer Metastasis Rev, 2010; 29: 483-502

18. Kim MY, Trudel LJ, Wogan GN. Apoptosis induced by capsaicin and resveratrol in colon carcinoma cells requires nitric oxide production and caspase activation. Anticancer Res, 2009; 29: 3733-3740

19. Li CQ, Wogan GN. Nitric oxide as a modulator of apoptosis. Cancer Lett, 2005; 226: 1-15

20. Sikora AG, Gelbard A, Davies MA, Sano D, Ekmekcioglu $S$, Kwon J, Hailemichael $Y$, Jayaraman $P$, Myers JN, Grimm EA, et al. Targeted inhibition of inducible nitric oxide synthase inhibits growth of human melanoma in vivo and synergizes with chemotherapy. Clin Cancer Res, 2010; 16: 1834-1844

21. Ekmekcioglu S, Ellerhorst JA, Prieto VG, Johnson MM, Broemeling LD, Grimm EA. Tumor inos predicts poor survival for stage iii melanoma patients. Int $\mathrm{J}$ Cancer, 2006; 119: 861-866

22. Kim JH, Kim MY. Immature citrus fruit extracts enhance the apoptosis inducing potential of cisplatin in human malignant melanoma a375 cells via regulation of nitric oxide and inhibitor of apoptosis family (iap) J Life Sci, 2014; 24: 454-460

23. Yu Z, Wang W, Xu L, Dong J, Jing Y. D-limonene and dcarvone induce apoptosis in hl-60 cells through activation of caspase-. Tradit Med, 2008; 3: 134-143

24. Ahamad MS, Siddiqui S, Jafri A, Ahmad S, Afzal M, Arshad M. Induction of apoptosis and antiproliferative activity of naringenin in human epidermoid carcinoma cell through ros generation and cell cycle arrest. PLoS One, 2014; 9: e110003

25. Yoshigai E, Machida T, Okuyama T, Mori M, Murase $H$, Yamanishi $R$, Okumura $T$, Ikeya $Y$, Nishino $H$, Nishizawa M. Citrus nobiletin suppresses inducible nitric oxide synthase gene expression in interleukin-1betatreated hepatocytes. Biochem Biophys Res Commun, 2013; 439: 54-59

26. LaCasse EC, Mahoney DJ, Cheung HH, Plenchette S, Baird S, Korneluk RG. lap-targeted therapies for cancer. Oncogene, 2008; 27: 6252-6275

27. Xie K, Huang S, Dong Z, Juang SH, Gutman M, Xie QW, Nathan C, Fidler IJ. Transfection with the inducible nitric oxide synthase gene suppresses tumorigenicity and abrogates metastasis by $k-1735$ murine melanoma cells. J Exp Med, 1995; 181: 1333-1343

28. Juang SH, Xie K, Xu L, Shi Q, Wang Y, Yoneda J, Fidler IJ. Suppression of tumorigenicity and metastasis of human renal carcinoma cells by infection with retroviral vectors harboring the murine inducible nitric oxide synthase gene. Hum Gene Ther, 1998; 9: 845-854

29. Kroumpouzos G, Eberle J, Garbe C, Orfanos CE. P53 mutation and $c$-fos overexpression are associated with detection of the antigen vla-2 in human melanoma cell lines. Pigment Cell Res, 1994; 7: 348-353.

Trop J Pharm Res, June 2016; 15(6): 1174 